\title{
Kesäyliopistolaitos alueellisena ilmiönä
}

KARI KANTASALMI

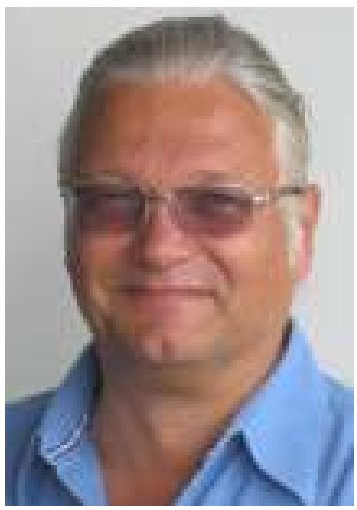

Kesäyliopiston juuret ovat ylioppilaiden valmentamisessa yliopistoopiskeluun sekä sittemmin myös kansakoulunopettajien jatkoopintotarpeissa. Nimestään huolimatta kesäyliopisto ei ole eikä ole ollut osa yliopistoa, vaan se on paikallinen yhdistys, jonka merkitys on valtakunnallinen. Nykyisin kesäyliopisto sijoittuu vapaan sivistystyön ja yliopiston kiinnostavaan rajamaastoon. Kirjoittaja tarkastelee, miten erilaiset sisäisen ja ulkoisen alueellistamisen muodot ovat vaikuttaneet kesäyliopistolaitoksen synnyssä ja myöhemmässä muutoksessa.

Kesäyliopistolaitosta kokonaisuutena käsittelevää tutkimusta ei ole aikuiskasvatuksen piirissä juurikaan tehty. Aukon täyttämiseksi on useita mahdollisuuksia. On olemassa verraten runsaasti yksittäisten kesäyliopistojen historiikkeja. Myös yliopistolaitoksen historiankirjoitus on sivunnut aihetta, sillä monien yliopistojen perustamisen taustalla oli kesäyliopistoyhdistyksiä. Lisäksi on kesäyliopistojen toiminnan kuvauksia eri ajankohdissa sekä lukuisia mietintöjen yhteydessä tehtyjä selvityksiä. Historiikkien käyttömahdollisuudet vaihtelevat sen mukaan, kuinka teoreettisesti tietoista historiankirjoitus on ollut. Tässä artikkelissani keskustelen siitä, kuinka kesäyliopiston historiallisesti muodostunutta yhteiskunnallista kompleksisuutta voitaisiin pyrkiä tavoittamaan. Katson ilmiötä alueelliselta kannalta, sillä tämä korostus on viimeaikoina nostettu selvästi esille kesäyliopistojen normiohjauksessa. Yhteiskuntaanalyysin tuella tarkastelen ohjaussemantiikan muotojen muutosta rakenteellisissa yhteyksissään. Analysoin käsitteitä ja koettelen sosiologian ajatteluvälineitä. Näin avaan teoreettisia näköaloja tämän oppilaitostyypin omintakeiseen historiaan.

Pedagogisessa ajattelussa - siis kasvattamisen, opettamisen, opiskelun ja oppimisen prosesseja sisältä katsottaessa - on luontevaa kohdentaa huomio näiden käytäntöjen alueellisiin ja tilallisiin ulottuvuuksiin. Tällöin käsitys relevanteista aluerajauksista muodostuu havainnoitavien käytäntöjen kautta ja niiden yhteydessä. Näin voidaan käsittää vaikkapa kesäyliopistolaitokselle ominaisen pedagogisen tilan tuottamista. Yhteiskunnan kokonaisuutta voidaan puolestaan ajatella relationaalisesti ja erilaisten sosiaalisten käytäntöjen rakenteistamina systeemeinä (Luhmann ja Giddens) tai kenttinä (Bourdieu). Lakiasäätävälle sekä laajemmin ymmärretyille valtio- ja markkinavälitteisille kesäyliopistojen ohjauskäytännöille on puolestaan luontevaa havainnoida koulutuskäytäntöjä kansallisvaltion sisällä ennalta muodostettujen (a priori) hallinnon ja/tai hallinnan aluekategorioiden kautta (esimerkiksi kunta, seutukunta, lääni, valtio ja sen rajat ylittävät aluekokonaisuudet). Molempien mainittujen havainnointikulmien käytännön järjen suhteen voidaan kysyä, minkälaisessa yhteiskunnassa kesäyliopistolaitoksen kompleksisuutta analysoidaan?

Analyysin jäsentyessä hallinnollisin käsittein syntyy helposti vakuuttava illuusio sen käytännöllisyydestä. Kesäyliopiston nykyistä kompleksisuutta saatetaan kuitenkin tavoittaa paremmin abstraktimpien välineiden ja refleksiivisemmän analyysin kautta. Tällaisen käsitteistön käytännöllisyys saattaa ilmetä tarkempana kuvauksena ja nykyhaasteiden parempana tunnistamisena. Mi- 
käli teemme yhteiskuntateoreettiset ennakko-oletuksemme näkyviksi, voimme tunnistaa myös poliittis-hallinnollisia havaintoyksikköjä abstraktimpien kategorioiden soveltamisen käytännöllisyyden. Luhmannin edistämä teoria funktionaalisesti eriytyneestä yhteiskunnasta tarjoaa kaksikin kommunikaation ensisijaisuutta painottavaa suuntaa tällaiselle ajattelulle: (1) monien eriytyneiden tarkasteluhorisonttien pyrkimyksen tulla yhteen nykyisyyksien yhteiskuntana (Nassehi 2004) ja (2) käsityksen maailman yhteiskunnasta (Stichweh 1996). Etenen nyt kuitenkin (aikuis)kasvatuksen/ koulutuksen ja sivistyksen ajatuksen suuntaamille käytännöille luontevasta toimijoiden luokituskamppailujen keskeisyyden oletuksesta (Bourdieu), mutta esittelen myös mahdollisuuksia, joita tarjoutuu kun yhteiskuntaa tarkastellaan kommunikaation perustavanlaatuisuuden oletuksesta käsin (Luhmann).

Semanttisen ja yhteiskuntarakenteellisen kytkennän tarkastelussa käytäntöjen toimijat ovat siis lähtökohtana - eivät yhteiskunnallisten käytäntöjen funktionaalinen eriytyminen ja osajärjestelmien rajautumista tukeva kommunikaatio (vrt. Luhmann). Kyse on käytäntöjen etenemisestä oppilaitostyypin yhteiskunnallisia kytkentöjä uusintavassa ja muuttavassa yhteydessä. Toimijalähtöinen (Giddens ja Bourdieu) tarkastelusuunta painottaa systeemisten muotojen historiallistavaa ei funktionaalistavassa mielessä nykyistävää analyysia, missä tapahtumat nähdään vain eroina (Luhmann). Tällöin alueellistumisen ja tilallisuuden näkökulmat painottuvat siten, että sekä analyysin kohteeseen että analyysin kategorioihin kohdistetaan historiallistamisen metodinen vaatimus siis eräänlainen toisen asteen havainnoinnin tuoma refleksiivisyyden lisäys (Luhmann). Lähestymistapa, missä korostetaan paikan ja tilan ulottuvuuksia toimijoiden merkityksenannon kamppailuissa ja analysoidaan tuotettujen konstruktioiden vaikutuksia toimijuuden näkökulmasta, saattaa tarjota joitain kiinnostavia tiedostusetuja kesäyliopistolaitoksen alueellisuuden muutosten tarkastelulle. Painotan nyt siis kesäyliopistolaitoksen rakenteen ja semantiikan rinnakkaiskehityksen historiallistavaa analyysia. Samalla liityn yleisempään keskusteluun alueen ja tilan käsitteiden tarjoamista mahdollisuuksista (ks. Kantasalmi 2008, 151253). Empiirinen kysymys kuuluu: kuinka erilaiset sisäisen ja ulkoisen alueellistamisen muodot ovat olleet kesäyliopistolaitoksen synnyssä ja muutoksissa vaikuttavina?

\section{Kesäyliopistolaitoksen muuttuvan alueellisuuden ongelma}

Luutonen $(1983,130)$ jaksotteli kesäyliopistolaitoksen kehitystä seuraavasti: (1) kesäyliopistojen esihistoria 1959 asti (2) ekspansio vuoteen 1969, (3) 1970-79 kesäyliopistojen ensimmäinen sopeutuminen ja identiteetin löytyminen tai muotoutuminen ja (4) uusi sopeutumisvaihe eli aikuiskoulutuksen laadullisen kehittämisen vaihe vuodesta 1980 alkaen. Suosittelen problematisoimaan esitetyn jaksotuksen ja ylipäänsä yksiulotteisen kalenteriajallisuuden tarkastelun. Keskustelen refleksiivisemmin ja prosessia paremmin kuvaavista organisoitumisvaiheista: (1) oppilaitosmuodon perustava vaihe vuodesta 1903 vuoteen 1912, (2) oppilaitostyypin yleistymisvaiheen päättyminen 1972, mutta paikkakuntakohtaisten toimintayksiköiden alueellisen peittävyyden kasvun jatkuminen, (3) opiskelijamäärien ekspansiojaksot 1963-72 ja 1974 $1992 \mathrm{ja}$ (4) oppilaitostyypin yhteiskunnallisen merkityksen uuden etsikkovaiheen avautuminen1990luvun alkupuolella. Vaiheistukseni heijastelee kesäyliopistolaitoksen organisoitumiskamppailujen käsitteenmuodostuksen strategioiden vaihtelua suhteessa vaikuttaviksi osoittautuneisiin rakenteellisiin hyytymiin. Ajallisuuden tarkastelu kestona nostaa esille jatkuvuuksia vaiheistuksen taustalla. Erilaisten ajallisuustasojen rinnakkaisuus ja päällekkäisyys toimijoiden nykyisyyksissä on organisoitumisen keskeinen osatekijä - se on myös avain oppilaitostyypin muuttuvan yhteiskunnallisuuden relationaaliseen kuvaamiseen.

Seuraavien huomioideni taustalla on Jyväskylän kesäyliopiston arkistojen, kesäyliopistokomiteoiden mietintötekstien sekä Suomen Kesäyliopistot ry. toimintakertomusten tutkimusta. Lisäksi on käytetty yliopistojen ja kesäyliopistojen historian esityksiä. Semantiikan muotojen analyysissa olen tuonut aikuiskasvatustieteellisessä keskustellussa elävät pedagogisen tradition refleksiokäsitteet modernia yhteiskuntaa havainnoivan sosiologisen diskurssin yhteyteen. Jäsentäjänä on toiminut modernin koulutuksen organisaatiorajapinnan mallinnus (ks. Kantasalmi 2008, 94-118). Kesäyliopistoa tarkastellaan siis suhteessa vakiintuneen koululaitoksen yhteiskunnallisesti täsmentyneempiin käytäntöihin. Kesäyliopistolaitoksen synnyn kontekstissa mm. virkamieskoulutukseen täsmennetty yliopisto oli osa vertikaalista organisaatiorakennetta. Yliopistoon johtavan koulun ja sitä edeltävän koulutuksen abstrakti yhteiskun- 
nallinen systeemisyys saattoi olla kesäyliopistojen synnyn kannalta merkittävää. Kyse oli myös yliopistolaitoksen horisontaalisesta eriytymisestä - toisen yliopiston odotuksesta ja uusien korkeakoulutyyppien (tekniikka, kauppa jne.) emergenssistä.

On kuitenkin huomattava, että nimestään huolimatta kesäyliopisto ei ole koskaan ollut varsinaisesti osa yliopistoa, vaan eräänlainen yliopistolaitoksen rajapinnan järjestely, jolla kuitenkin on ollut huomattavaa pysyvyyttä. Nimestään huolimatta kesäyliopistoissa annettu opetus ei ole myöskään enää aikoihin sijoittunut pääsääntöisesti kesäaikaan eli yliopistojen opetusperiodien ulkopuolelle. Avoimen yliopisto-opetuksen osalta on kuitenkin ollut kyseessä yliopisto-opetuksen ja opiskelun sisäinen ja tiettyyn pisteeseen asti tutkintosertifioitu laajennusmahdollisuus.

Nykyisin kesäyliopisto määritellään myös vapaan sivistystyön osaksi. Kesäyliopistojen syntyvaiheessa toimijoiden käsitteet olivat tässä suhteessa vielä kiinnostavasti vakiintumattomia, kun käytössä olivat mm. pedagogiset refleksiokäsitteet kansanvalistus ja kansansivistys ja sen haastanut työväensivistys. Näiden käsitteiden sitomien käytännöllisten teemojen ohessa ja osin niiden sisällä kulki myös pitkäkestoinen ja koulutuksen sisäisen alueellistamisen kannalta olennainen naissivistyksen teema.

Toimijuuden luokituskamppailujen rakenteistavien vaikutusten näkökulmasta voidaan täsmentää niitä pedagogisia tiloja, joissa kesäyliopistolaitos syntyi sekä sellaisia, joiden kautta se nykyisin pyrkii edistämään sivistystä. Oppilaitostyypin organisoitumista tukeneet pedagogiset tilat eivät ole olleet missään vaiheessa täysin yhteneväisiä niiden pedagogisten tilojen kanssa, joita modernin koulutuksen abstrakti systeemisyys, kuten diplomien symboliset muodot (Giddens) strukturoivat. Kyseessä on ollut osittainen päällekkäisyys, jonka käsitteellinen tavoittaminen on kesäyliopistolaitoksen muuttuvan yhteiskunnallisen merkityksen analyysin olennainen haaste. Oppilaitostyypin suuntautumisongelmien ja ratkaisujen täsmentäminen muuttuvissa historiallisissa puitteissaan auttaa näiden rajapintojen tunnistamisessa. Kesäyliopistolaitoksen yhteiskunnallisen muutoksen käsittämisen kannalta tämä on tärkeää. Onnistunut historiallisen kehityksen täsmennys on puolestaan laitoksen ajankohtaisiin haasteisiin vastaamisen edellytys. Voidaan jo kysyä, mitä mahdollisuuksia sisältää se, että oppilaitos- tyypin julkishallintoa (administration) sekä prosessihallintaa ja johtamista (management) suuntaava laki vapaasta sivistystyöstä (632/1998) ja sitä täydentävä asetus (805/1998) määrittävät kesäyliopistolaitoksen vapaan sivistystyön organisatoriseen kokonaisuuteen kuuluvaksi. Rahoituksessa kesäyliopistot rinnastettiin ylläpitäjiensä sijaintipaikkakuntien kunnallisiin kansalais- ja työväenopistoihin. Kustannuslaskennan näkökulman lisäksi kesäyliopistolaitokselle täsmentyi myös käytännöllinen horisontti, joka nyt on alueellisessa mistä havainnointipisteestä ja miten se milloinkin ymmärretäänkin - vapaassa sivistystyössä ja avoimessa yliopisto-opetuksessa. Mitä mahdollisuuksia tämä aseman määritys avaa ja kuinka tuon kontingenssin kanssa voisi toimia?

\section{Suomalainen tiede, kansanvalistus, kansansivistys ja vapaa sivistystyö}

Matti Sainio (1962, 24) katsoi kesäyliopistojen merkityksen vapaan kansansivistystyön tekijänä olleen vähäinen. On kuitenkin muistettava, että kesäyliopistolaitoksen perustamisvaiheessa kansakoulu oli kansansivistystyön ydinorganisaatio. Kansakoulunopettajat olivat tuolloin kansanvalistuksen keskeinen voima, jolle kesäyliopiston merkitys muodostui suureksi. Tästä iskujoukosta itsetietoisesti eriytyvän vapaan kansansivistystyön ongelmalliseksi osoittautuvat ammatillistamispyrkimykset puolestaan olivat vasta tulollaan. Tätä heijastelee se, että vapaan sivistystyön käsite vakiintui käytäntöjen itseymmärrystä tietoisesti edistävään ajatteluun vasta valtiollisen itsenäisyyden ensimmäisinä vuosikymmeninä. Ei tule myöskään unohtaa, että ne Helsingin Aleksanterin yliopiston professorit, jotka rakensivat ensimmäisten kesäyliopistojen tilaa, kuljettivat kansanvalistuksen ja -sivistyksen jatkumoa ilmentäviä vaikuttamia tieteellisten organisaatiopyrkimystensä ohessa miksi?

Saadakseni käyttökelpoisen otteen voimassa olevan lakitekstin "vapaasta sivistystyöstä" kohdennan huomiota sen ytimessä olevaan sivistyksen käsitteeseen. Pohjoisen valistuksen projektissa emme voi kiertää siihen suuresti vaikuttaneen saksalaisen pedagogiikan traditiota. Tätä Siljander (2002, 33-36) ajoi takaa kiteyttäessään, että Bildung-käsitteen sitoma yleisinhimillisyyden idea aikanaan rikkoi tiettyjä sosiaalisia hierarkioita ja korosti modernin kansalaisen kykyä itsenäisen ajattelun turvin ylittää sitä vierasmääräytyneisyy- 
den ajatusta, jota kasvatuksen ja koulutuksen käsitteiden voi katsoa kuljettavan mukanaan. Luhmannin $(2002,187$ - 188) mukaan klassisessa muodossa sivistyksen käsite yritti imeä itseensä yksilöllisyyden ja ihmisyyden -erottelun. Uushumanistisessa perinteessä käsite asettui edistämään ihmisyyden kohottamista lisääntyvän yksilöllisyyden oloissa. Sivistys pyrki osoittamaan kasvatuksen mielen (Sinn) ja käsitteenä se alkoi saada refleksiokäsitteen painoa. Kyse ei ollut enää sivistyksen konkreettisista tunnuspiirteistä, vaan yksilöllisyyden määrittämisestä ihmisyyden ja maailmanperspektiivien sisäistämisenä. Hyväksyn tämän analyysin ja seuraan Luhmannia myös pidemmälle.

Sosiologiselta kannalta arvioiden, Luhmann $(2002,187)$ näki sivistyksen menettäneen prosessuaalisen luonteensa. Siksi yhteiskunnassa huomio kääntyy pedagogisointiin ja yksilöiden parissa ideaan itsenäisesti omaksutusta sivistyksestä. Yhteiskunnallisten järjestelmien keskinäissuhteiden järjestymisessä sivistyksen käsitteen merkitys Saksan mailla - kenties myös meillä-saattoikin olla ennen muuta siinä, mistä Luhmann ja Schorr (1988) puhuivat. Kyseessä oli muutoskonteksti, missä koulutustapahtumien määrällinen kasvu eli koulutuksen yleistyminen käsitettiin ensikertaa todennäköiseksi. Kasvatuksen ja talouden järjestelmien rakennekytkentää ilmentää uran koodi. Sen puitteissa tuli sivistyksen käsitteestä väistyvän säätyjärjestyksen kontingenssin hallinnalle kaava, joka turvasi mahdollisimman suuren sisään sulkevuuden mahdollisimman siedettävällä tavalla - ei nimittäin ollut itsestään selvää, että rahvas ja perinteinen sivistyneistö voisivat jakaa koulupenkkinsä. Kyse oli periaatteellisen inkluusion (vapaus, veljeys ja tasa-arvo) avaamista koulutuskäytäntöjen lisääntymisen ja sosiaalisen alan laajentumisen mahdollisuuksista. Nämä toimivat myös tieteen epäsuoran inkluusion keskeisenä yhteiskunnallisina risteyminä (Stichweh 2005). Näin nähden olisi toki analysoitava myös erilaisia ekskluusion muotoja tieteen ja koulutuksen organisaatioissa, sillä näissä päätöksenteon olennaisissa konteksteissa periaatteellinen inkluusiosemantiikka (esim. koulutuksen tasa-arvo tai suomenkielinen tiede) vaatii aina puitesidonnaisia ja ongelmalähtöisiä ratkaisujaan; vaikkapa kesäyliopistoa!

Ellei kesäyliopistolaitoksessa niin yliopiston yhteydessä kuitenkin korostuvat tieteellisen tiedon ja paikallisten tutkimuskäytäntöjen kytkennät opetuksen ja opiskelun kautta tapahtuvaan tieteen uusintamiseen. Sivistys ei kuitenkaan välttämättä tarkoita kulloisenkin aikakauden tieteellisen tiedon sosiaalista levittämistä kasvatuksen ja koulutuksen kautta etenevän tieteen popularisoimisen ja epäsuoran inkluusion (Stichweh 2005) merkityksessä. Niinpä Mehtonen (2005) huomauttaa myös J.V. Snellmaniin viitaten - että sivistyksessä oli kyse tietynlaisesta tieteenelämänmuodosta ja sen kautta tapahtuvasta itsensä muodostamisesta (Bildung durch Wissenschaft). Modernin yksilöllisyyden korostumista aavistelleen Kantin(1995) kuuluisa "vastaus kysymykseen, mitä on valistus" korosti rohkeutta itsenäiseen ajatteluun, mutta tieteellisen järjenkäytön ohella kyse oli myös arvostelukyvystä (Urteilskraft), jonka merkitys sivistysprosessin osana korostuu samalla, kun tiede autonomisena ja itse määräytyvänä praksiksena joutuu yhä tiiviimmin itsensä ulkopuolelta määrittyvän poiesiksen haastamaksi (ks. Mehtonen 2005, 134-137, vrt. Siljander 2002, 34). Kantin Vastaus kysymykseen: Mitä on valistus? on myös kehote historiallisen aikamme pysyvään kritiikkiin. Itseemme kohdistama filosofinen kritiikki on samalla meille asetettujen rajojen historiallista analyysia ja näiden rajojen ylittämisen mahdollisuuden kokeilua (ks. Foucault 1984, 32-50).

Mikäli kesäyliopiston itseymmärryksen muodostus ajankohtaistaisi edellä mainittuja pedagogisen teorian filosofisestikin tärkeitä teemoja, niin olennainen kysymys kuuluisi; onko sivistyksen mahdollisuus ensisijaisesti koulutuksen systeemin sisällä vai sen ulkopuolella? Luhmann $(2002,186$ 203) katsoi, että kirjapainotaidon yleistymisen jälkeisessä maailmassa yhteiskunta reagoi sivistyksen käsitteellä siihen - nykyisin siis yhä intensiivisempään - kokemukseen, joka seuraa tietoisuutta siitä, että tietojäsennykset ja osaaminen muotoutuvat myös kasvatus- ja koulutusjärjestelmän sosiaalisen kontrollin ulkopuolella. Yhteiskunnan kasvatusjärjestelmä reagoi tällä käsitteellä tappioihin mm. rooliteoreettisesti käsiteltävien odotusten alueella. Niinpä käsitteellä yritetään tarttua vaikkapa opettajan roolia pakenevaan itse oppimiseen. Ei ole itsestään selvää, kuinka elinikäisen oppimisen korostus ja koulumuodon pönkittämät opettajaroolin odotukset kohtaavat 2010-luvun vapaassa sivistystyössä. Sivistyksen käsitteen muodonmuutos 1900-luvun Suomessa saattoi kuitenkin ilmentää pääpiirteissään em. kaltaista semantiikan ja yhteiskuntarakenteen suhteen muutosta. Tällaisen hypoteesin valossa vapaa sivis- 
tystyö on kiinnostava valtiollisen itsenäisyyden aikana vaikuttanut käsite, jonka rinnakkaisevoluutiota koulutuksen organisaation kanssa tulisi huolella tutkia.

Tällöin on kuitenkin muistettava, että käsitteen avaama sivistyksen vapauden yhteiskunnallinen teema oli kesäyliopistolaitoksen syntyvaiheessa ja maamme ensimmäisen tasavallan kontekstissa melko omintakeisesti poliittisen järjestelmän kuumentama. Ruotsalaisen yliopiston ja oppineiston perinne sai yli sadan vuoden ajan Venäjän imperiumin muuhun yliopistolaitokseen nähden suhteellisen autonomisen aseman, mutta ei vailla sen vaikutuksia. Myös kansallisen liikkeemme sivistyssemantiikan korostukset on syytä pitää mielessä. Romanttisen kansakäsityksen haljettua sisällissodassa, oli kirjaoppineisuudesta loitolla olleen työkansan sivistysprosessien suunnasta suuri huoli. Syntyikin kokonainen organisaatioiden verkosto ja sitä vastaava ohjaussemantiikka, missä vapaan sivistystyön ohjelmakäsite sai merkittävän refleksiokäsitteen aseman. Mutta normalisoituiko käsite lopulta vuonna 1999 vain julkishallinnolliseksi luokituskategoriaksi? Jo käsitteen käytännöllisellä alkutaipaleella ilmeni sivistyksen vapauden rajojen määrittämistä eli käsitteen kaventumista. Nämä tapahtuivat yhteydessä koulutuksen yleistymisen ja laajentumisen tuottamaan kansalaisen elämäkulun pelitilan muutoksiin. Kesäyliopiston syntyvaiheen kommunikaatiokontekstissa keskeistä oli sivistyksen käsitteen värähtely kansansivistyksen ja työväensivistyksen käsitteiden kautta havainnoivien käytäntöjen välillä. Vapaan sivistystyön merkitysosuvuutta tavoitellut semantiikan muutos stabilisoi sisällissodan jälkeiselle kontekstille mahdollisella tavalla poliittisen järjestelmän ja (aikuis)kasvatuksen jännitteisyyttä. Samalla eriytyi myös aikuiskasvatuksen organisoitumisen omalle dynamiikalle operatiivista pelitilaa. Se mahdollisti 1970-luvun aikuiskasvatuskäytäntöjen kommunikaation tihentymisen aikuiskoulutuksen käsitteen suunnassa.

\section{Alueellisuuden ulottuvuudet perustavassa vaiheessa}

Kesäyliopistolaitosta perustavan tilan tuottamisessa oli kyse yliopisto-organisaation perinteisen kaksoiskohdennuksen (tieteellisen tiedon tuottaminen ja tiedon yhteiskunnallinen kontrolli koulumuodon sisällä) kiinnostavasta päällekkäisyydestä. Taustalla olivat suuren näyttämön tapahtumat eli vuoden 1848 jälkeinen Eurooppa. Prosessin alun pienenä näyttämönä toimi Jyväskylä. Pienestä perifeerisestä asemastaan huolimatta kaupunki oli valtakunnallinen näytön paikka, sillä näiden mittakaavojen väliin sijoittuvan alueellisen merkityksenannon topoksena oli suomenkielinen ja -mielinen sivistys. Kaupunki oli muotoutuvan kansallisvaltion ensimmäisen suomenkielisen yläalkeiskoulun, kansakoulunopettajaseminaarinsa ja ensimmäisen suomenkielisen tyttökoulunsa vuoksi muodostunut 1800-luvun jälkimmäisen puoliskon aikana väestömääräänsä nähden harvinaiseksi suomenkielisten koulutusmahdollisuuksien keskukseksi. Kun syksystä 1862 alkaen yläalkeiskoulu (vuodesta 1873 lyseona) toimi yliopistoon johtavana, se ei enää ollut paikallinen oppilaitos, vaan alkoi koota oppilaita laajalti suuriruhtinaskunnasta.

Ensimmäiset ylioppilaat Jyväskylän alkeisopistosta valmistuivat 1865 . He olivat saaneet intensiivisen valmennuksen myös ruotsinkielessä, jota ilman vielä tuolloin ei yliopisto-opiskelu Helsingissä olisi ollut mahdollista. Sainio $(1962,1)$ korosti, että Jyväskylän kesäyliopistossa ensisijaista olisi ollut ylioppilaiden valmistaminen yliopisto-opiskeluun ja toiminnan painopisteen siirtyneen vasta myöhemmin kansakoulunopettajien jatko-opintoihin (vrt. Kangas 1992, 63). Kesäyliopistolaitosta käyttivät alun alkaen vähemmistönä yliopiston opiskelijat. He mm. jouduttivat pakollisten kielikokeiden kautta opintojansa lähempänä kotiseutuaan. Tällaista palvelua ei kuitenkaan olisi voitu tarjota ilman laajempaa, suhteellisen vakaata ja maksavaa osallistujapohjaa. Sen tarjosivat koululaitoksen opettajien koulutustason professionalistiset kohottamispyrkimykset ja ammattiryhmän koulutustason (mm. ylioppilaspohjan yleistyminen) tosiasiallisen kohoamisen rakenteellinen tuki. Myöhemmissä vaiheissaan kesäyliopistolaitos organisoi tämän palvelun alueellisesti hajautetusti. Erityisen merkittävä kesäyliopisto oli kansakoulun opettajiston professionalismissa, joka ei olisi voinut saada yhtä vaikuttavaa yliopistollista tukea ilman tieteellisen tiedontuotannon kenttämme omintakeisia sisäisiä kamppailuja. Tässä oli keskeistä yliopisto-organisaation vertikaalisten ja horisontaalisten rajapintojen dynamiikka (ks. Kantasalmi 2008 ja 2010).

Perustavassa kontekstissa kohtasivat homo academicus toimijatyypin suomalaistuminen (kieli ja mieli) sekä keskisäädyn ja henkisen työn ammatillinen organisoituminen eli keskiluokan esiin- 
nousu. Kansakoulun opettajisto oli välittävä ryhmä yleisemmän keskiluokan teeman yhteydessä"landets första fackförening för intellektuella" (ks. Allardt 1966, Metsikkö ja Oksanen 1943, ja Kantasalmi 2008, 273-275). Kesäyliopiston pedagogista tilaa rakennettiin kamppailemalla symbolisen järjestyksen alueella. Sivistyksen kylvön retoriikan relevantin yleisön laajuus toimi periaatteellisen inkluusion takeena. Lupauksen tuli olla riittävän kattava tyyliin "kansakoulu joka kylään". Mutta periaatteellinen inkluusiosemantiikka lisää vain mobilisaation todennäköisyyttä organisaatioiden kohtaamien ekskluusion ongelmien edessä. Professionalismin strategiassa inklusiivinen ja eksklusiivinen aspekti elävät rinnakkain (Kantasalmi 2010). Se tarkoitti kansakoulunopettajain ammatillisten kohottautumispyrkimysten kulkemista yliopiston täsmentämän kulttuurisen tilan kautta, missä tiede ja sen alakohtainen organisaatiorakenne kuitenkin usein jäykistää sisäisen ja ulkoisen rajapintaa. Miksi yliopisto avautui kahden opettajakunnan (so. yliopistoissa koulutetut oppikoulunopettajat ja seminaarissa koulutetut kansakoulunopettajat) jaon edessä ja edisti sen ylittämiseen tähtäävää toimintaa kesäyliopiston tilassa?

Vastaus ei ole Aleksanterin yliopiston professorien syttyminen yliopiston laajennusliikkeen tuontitavaraan (vrt. Sivonen 2000). Kyse oli yleisemmästä tieteen epäsuorasta inkluusiosta, joka kulkee kasvatuksen ja koulutuksen käytäntöjen kautta (Stichweh 2005). Kyse oli suomenmielisen akateemisen kentän muodostuksen kamppailusta, joka teki mahdolliseksi kesäyliopistolaitosta perustavan pedagogisen tilan organisoimisen. Kansakuntaa rakentavassa prosessissa oli akateemisen kentän sisäisissä kamppailuissa totuttu käyttämään akateemisen valistuksen käytännöllisiä kytkentöjä kentän ulkoisena tukipisteenä. Talousseuran maalaisvalistuksen ja yliopistotasoisen maatalousopetuksen organisoituminen on ehkä yliopistohistoriamme tunnetuin tällainen prosessi. Kansakunnan muodostaminen tarjosi muitakin käytäntökytkentöjä ja samalla rajapintojen mahdollisuuksia. Kesäyliopiston synnylle tärkeintä oli se, että pohjoisen kansanvalistuksen käytännön toimeliaisuuden rinnalla oli yliopiston sisälle jo varhain muodostunut myös pedagogiikan oppituoli, joka kiinnittyi germaanisen sivistyssemantiikan perinteeseen. Se oli osa kansakunnan rakentamisen strategiaa (ks. Kantasalmi 2008).

Vuonna 1838 perustetun Suomen Tiedeseuran Helsingin Kasarminkadulla sijainneen ns. Pöllö- län talon rauha oli jo siinä määrin järkkynyt Suomen tieteen kielen asemasta riideltäessä, että uusi Suomalainen Tiedeakatemia saattoi astua sen valtuuskuntaan loppuvuodesta 1908. Pöllölän professoreiden suomenmielisellä iskujoukolla E.N. Setälän, K. Krohnin ja E.G. Palménin oli suuri rooli vuonna 1912 tapahtuneessa Jyväskylän kesäyliopiston synnyssä. Tämä toimijaryhmä kehitti keskeiseksi työmuodokseen maaseutukaupungeissa vuodesta 1910 lähtien järjestetyt luentokurssit, jollaiset järjestettiin myös Jyväskylässä vuonna 1911 (ks. Ketonen 1959, 130-36). Tässä mielessä kansansivistyksellinen ulottuvuus oli alusta alkaen kesäyliopiston aloitteessa mukana, mutta yliopistolaitoksen tiedepoliittiseen puoleen tiiviisti kytkettynä.

Mallista oli epäselvyyttä, mutta nehän hioutuvat refleksiivisesti käytännössä. Yhtäällä toivottiin uutta alueyliopistoa ja toisaalla pidettiin alueellisen tutkimuslaitoksen ideaa realistisempana. Setälää ei voine pitää toisen suomalaisen yliopiston puolestapuhujana, sillä vuonna 1922 toimintansa aloittaneen Turun Suomalaisen yliopiston kanslerina ollessaankin (1926-35) hän pyrki vuonna 1919 omaksumansa linjan mukaisesti edistämään ajatusta tutkimuksen voimistamisesta Helsingin yliopiston "pienoisjäljennöksen" sijaan (ks. Ketonen 1997, 30-33). Jyväskylän osalta Kangas (1992, 85) nostaa niin ikään yhden professuurin paikallisen tutkimuslaitoksen ja kaupungin yliopistoyhdistyksen ajaman pienoisyliopistomallin vastakkainasettelun esille.

Kyse oli siis yksittäisten professoreiden, uusien tutkimusalojen tai sellaista asemaa tavoitelevien tutkimussuuntausten ja tiedekuntien kamppailusta. Tässä ei kannata väheksyä yliopiston kansansivistyksellisen rajapinnan dynamiikan merkitystä. Kesäyliopiston alkuvaiheen pöytäkirjoista ilmenevä opetustapahtumien järjestelyvastuun eriyttäminen yliopistollisten kesäkurssien valiokuntaan ja ns. vapaiden opintojen valiokuntaan kertoo tästä kaksijakoisuudesta. Kesäyliopiston yliopistopoliittisen merkityksen pisti merkille myös Suomen tiedeseuran sihteeri (1908-1921), Aleksanterin yliopiston rehtori Anders Donner vuoden 1912 syyslukukauden avauspuheessaan (Klinge 1990,108-109). Kun tiede uutta muotoa hakiessaan, kytkeytyy kasvatukseen ja koulutukseen, niin sen organisoitumiseen tulee koulutuksen organisoitumisen käytännön järkeä ja päinvastoin. Tässä on myös tieteen epäsuoran inkluusion ydin: kaikki eivät voi olla tieteen tekijöitä, mutta yhä useam- 
mat tulevat eri tavoin sen vaikutuspiiriin. Koulutuksen periaatteellinen universaalisuus sen kehitysprosessien refleksiivisyyden dilemmana on tässä historiallistavassa, mutta myös funktionaalistavassa mielessä tarkastellen olennaista (ks. Kantasalmi 2008 ja 2010). Tieteen popularisoimista ei myöskään tapahdu vain tiedejärjestelmän ulkopuolisessa kasvatuksessa ja koulutuksessa, vaan lisäksi tieteen sisäisissä käytännöissä (ks. Stichweh 2003).

\section{Kesäyliopistolaitoksen merkitys koulutuksen organisoitumisessa}

Oppilaitosmuodon perustava vaihe liittyi erityisellä tavalla yliopiston ja seminaarin nivellyksen horisontaaliseen rajapintaan. Kyse oli korkeakoulutuksen organisaation sekä sisäisestä että ulkoisesta alueellistamisesta. Sana kesäyliopisto tuli käsitteeksi hyvin erityislaatuisissa sosiaalisissa puitteissa. Koulutuksen organisoitumisen refleksiohistorian näkökulmasta katsoen sosiaalinen kenttä rajautui 1800- ja 1900-lukujen taitteessa kahden teeman erityisissä tulkintasuunnissa: (1) kahden opettajakunnan teeman professionalismiksi tulkittavassa mobilisaatiossa sekä (2) 1900-luvun alussa voimistuneen ruotsinkielisen oppisivistyksen yliopistovälitteisen kulttuurihegemonian murtamisessa, joka tapahtui muotoutuvan korkeakoulutuksen kielipoliittisesti sekä kansallisesti merkittäviksi nähdyissä kamppailuissa.

Ensimmäisessä suunnassa kamppailivat yliopistossa koulutetut gymnaasien ja lyseoiden lehtorit (so. homo academicus) sekä kansansivistyksen iskujoukoksi seminaareista vuoden 1863 jälkeen kohonnut kansakoulunopettajisto (so. quasi homo acamedicus). Kamppailua määritti ensimmäisen ryhmän kielivälitteisen (ruotsi-suomi) rakenteellisen aseman muutokset kansakunnan kokonaisuutta muodostavassa prosessissa. Tähän yhdistyi valtion ja yksityisten oppikoulujen erottelu ja jälkimmäisten tendenssi päätyä valtion rahoittamaksi. Toisessa suunnassa kamppailivat Aleksanterin yliopiston professorit, joiden huolena kielirajan molemmin puolin oli tieteen suomalaistaminen. Viimeksi mainittu tarkoitti ennen muuta kamppailua tieteen kielestä. Nämä kaksi kamppailuareenaa yhtyivät osittain rajapinnalla, jota olen kutsunut yliopistoaikuiskoulutukseksi (ks. Kantasalmi 2008). Tämän kentän strukturaatiossa kansansivistyksen suuntaama koululaitoksen rakenteen organisointi ja kansakoulun aseman voimis- taminen sen osana synnytti kahden opettajakunnan teeman. Sen käsittely professionalistisen mobilisaatioprojektin puitteissa yhtyi oppisivistyneistön rakennemuutokseen ja teki mahdolliseksi oudon emergenssin: kesäyliopisto ei nimestään huolimatta ollut osa yliopistoa, vaan paikallinen yhdistys, jolla oli valtakunnallinen merkitys. Tämän alueelliset vaikutukset olivat laajoja ja kauaskantoisia: kesäyliopistot ovat täällä tänään.

Helsingin professoreiden autonomian ajan lopun kesäkurssitoiminta sijoittui lähinnä Turkuun ja Jyväskylään. Yliopistolaajennuksen kansainvälisen liikkeen sijaan painotan tämän käsittämisessä kotikutoisempaa koulutusvälitteisen sosiaalisen elämän järjestysten muutosta - kielipoliittista kamppailua ja käytännöllistä akateemisen valistuksen perinnettä, missä myös ruotsinkielisten liberaalien ja elinkeinoelämän yliopiston valtiollista luonnetta kyseenalaistava dimensio oli merkittävä. Klingen (1990, 106-111) selostus vihjaakin siihen, että Turun 'kesäkurssit" ja Jyväskylän "kesäyliopisto" sisälsivät erilaisia "paikallispatrioottisia" painotuksia. Ensin mainitut alkoivat ruotsinkielisinä luentoina jo 1903. Jälkimmäinen kytkeytyy puolestaan vuonna 1911 viritettyyn "kesäsemesterin" ajatukseen ja johti kutsumaan vuonna 1912 Jyväskylässä aloitettua toimintaa kesäyliopistoksi. Tämä puolestaan osaltaan innoitti myös ruotsinkielisiä voimistamaan kesätoimintaansa vuodesta 1913. Akademiska sommarkurserna $i$ A bo:n opettajakunta sulki sisäänsä Helsingin yliopiston professorien lisäksi myös lyseon, seminaarin, kansanopiston ja kauppaopiston opettajia. Kesäkurssitoimintaa järjestettiin Turussa myöhemmin myös suomeksi. Useamman kesän opintojen seurauksena oli mahdollista suorittaa kasvatusopin tutkinto ja filosofian kandidaatin tutkintoon rinnastuva taloudellinen tutkinto (ks. Klinge 1990, 106-111). Suomenkielistä yliopistokysymystä hämmensivät paikkakuntien esille nousseet voimakkaat intressit. Myös Lahden korkeakouluvaliokunnan laaja selostus "Korkeakoulukysymyksiämme" vuodelta 1911 kertoo näistä voimakkaista paikallisodotuksista (ks. myös Klinge 1990, 108-111; Kangas 1992 ja Kantasalmi 2008).

Turussa, mistä yliopisto oli tempaistu pois vuonna 1827 ja gymnasium täyttänyt näin syntynyttä tyhjiötä, näyttäisivät kesäkurssit johtaneen ennen valtiollisen itsenäisyyden aikaa toisenlaiseen painotukseen ja opiskelijoiden profiiliin (ks. Klinge 1990, 109 ja Nordström 1968, 10, 14-15, 17). Yliopistoaikuiskoulutuksen kenttä paikallisine 
yhdistyksineen ja oppilaitoksineen kohottautui myös Åbo Akademin ja Turun suomalaisen yliopiston synnyn operatiiviseen perustaan. Siellä Arbetets Vänner oli ensimmäinen yhteistyöyhdistys, mutta myöhemmin kuvaan astui vuonna 1880 perustettu Svenska Bildningens Vänner, jonka professori A.O. Freudenthal -henkisestä piiristä oli kehittynyt myös Svenska folkskolans vänner. Se pyrki aluksi mobilisoimaan vapaan talonpojan (odalbonde ja odalmanklassen) kansansivistystä (ks. Nordström 1945, 15-21; Puntila 1944, 148 ja Cavonius 1982, 18-21). Omaa kesäaikaista toimintaa oli sittemmin oppilaitostyypin yleistyessä näissä uusissakin yliopistoissa. Kasvatusopin tutkinto veti kansakoulunopettajia ja muutakin opettajakuntaa myös Turun vuonna 1936 perustettuun kesäyliopistoon (ks. Sainio 1962, 24 ja Impivaara 1986, 20 ja 30). Yleisemminkin nähden tällaisessa paikalliskamppailujen (kansalaisyhteiskunta) ja yleistahdon (valtion) välisessä kehässä, joka tähtäsi yliopistojen tai filiaalien perustamiseen, vakiintui oppilaitostyypin yhteiskunnallinen asema (ks. Aaltonen 2000; Lackman 1998, 18-20, 27 ja 24-27; Laine 2005; Laurilehto 1994; Martikainen 2005; Nevala 1986; Nurmi 1995, 229; Vuorio 2006, 30-38).

Kesäyliopistojen organisoitumispäätösten yhteydestä vahvistuivat oppilaitostyypin yhteiskunnallisen merkityksen keskeiset dimensiot. Yleistymisvaiheen useammassa perustamisprosessissa tulee näkyväksi myös eräs koulutuksen organisoitumisen suomalainen toimintatapa. Kutsun sitä instituutioksi, sillä kyse on koulutuksen organisoitumisprosessien toimijuutta pitkäkestoisesti sitovasta, mahdollistavasta ja tavanomaisesta kaavasta. Se toimii ja tulee näkyväksi paikallisten resurssien investointina ja paikallisaloitteisuuden osoittamisena odotetun valtion panostuksen kautta palautuvassa kehässä. Kesäyliopistolaitoksen kehittyessä ja opiskelijamäärien kasvaessa aluehahmotukset muuttuivat ja retorisen nokkeluuden variaatio paikallisaloitteisuuden esittämisessä kasvoi, mutta instituutio ei muuttunut. Se voi kuitenkin olla muuttumassa uudessa etsikkovaiheessa, johon laitos tuli 1990-luvulla. Ammattikorkeakoulut saattoivat tosin vielä tarjota tukea instituution jatkuvuudelle. Edeltävien vaiheiden paikallisaloitteellisuutta ei kuitenkaan voida käsittää irrallaan akateemisen tiedontuotannon organisoitumisen kamppailuista. Kamppailun luonne vain muuttui tutkimuksen monien yleisöjen odotusten edessä. Kesäyliopiston yleistymisvaihetta määritti voimak- kaasti uusien yliopistojen perustamisen paikallisodotuksen horisontti. Uusien alueyliopistojen perustamisen kulminaatiopisteen (ei enää uusia) tultua ilmeiseksi kansankoulun opettajien seminaaripaikkakuntien ja tulevien kasvatustieteellisten tiedekuntien filiaalit olivat vielä pelin paikkoja. Tämän jälkeen kuntasektorin julkisten alojen täydennyskoulutusvelvoitteet opettajain ammattikuntaa laajemminkin varmistivat instituution uusintamisen perustaa. Kesäyliopiston paikallisuus alkoi tuolloin operoida yliopistojen täydennyskoulutuksen ja avoimen yliopisto-opetuksen projektikäsitteiden organisaatiovaikutusten paineessa. Selvemmäksi tämä tuli 1980-luvulla, kun instituutiota uusinnettiin koulutusmarkkinoiden kautta ja täydennyskoulutuskeskusten perustamisen odotushorisontissa. Yliopistolaitoksen sisäisen ja ulkoisen alueellistamisen tuella mm. Helsingin yliopiston aikuiskasvatuksen lahjoitusprofessuurin perustamisessa ilmeni tällainen toimintamalli.

Kansakoulunopettajat, mutta myös oppikoulun opettajat ja muu opettajakunta, kuten kansanopistojen opettajat, olivat alusta asti merkittävin osallistujaryhmä Jyväskylän kesäyliopistossa. Näin oli siihen asti, kunnes vuonna 1934 perustetun Jyväskylän kasvatusopillisen korkeakoulun perussääntöihin sisällytetty ajatus kesälukukaudesta muuttui käytännöksi (1937) ja kesäyliopisto siellä lakkautui. Vuosikymmenten kuluttua se kuitenkin herätettiin jälleen henkiin. Myös Turun yliopiston hoitokunnan 19.3.1921 vahvistamiin sääntöihin tuli maininta kesälukukaudesta, mutta yliopiston avajaisten (27.6.1922) jälkeen konsistorin ehdotuksesta (17.12.1922) tuo maininta poistettiin. Vuoden 1922 talousarvioon oli kuitenkin varattu määrärahoja kesä- ja ylimääräistä opetusta varten (Jäntere 1942, 329-330 ja 338 ja Ketonen 1997, 20). Ainoastaan Jyväskylän kasvatusopillisessa korkeakoulussa kesälukukausi muodostui kiinteäksi osaksi korkeakoulun toimintaa. Näin Jyväskylän järjestelyt sisälsivät siemenen 1960-luvulla aikana aktivoidulle kesälukukauden koulutuspoliittiselle teemalle, josta kuitenkin käytännössä luovuttiin. Toteutuessaan korkeakoulujen kesälukukausi olisi luultavasti ollut erillisen kesäyliopistolaitoksen tulevaisuudelle kohtalokas. Se olisi todennäköisesti typistänyt oppilaitostyypin yleistymisvaihetta ja laimentanut opiskelijamäärien ekspansiota. Jyväskylän yliopistossakin maininta kesälukukaudesta pudotettiin myöhemmin yliopiston asetuksesta. Näin myös siellä palattiin kesäyliopistotyyppiseen toimintaan. Ilman kesäyliopistolaitosta tus- 
kin olisi ollut samassa määrin mahdollinen se kansakoulun opettajistossa ensimmäisenä kiteytynyt ja yhden ihmisiän kulussa vuodesta 1864 vuoteen 1934 toteutunut koulutusvälitteisen sosiaalisen järjestyksen muutos, joka ilmenee kansallisvaltion synnyssä, keskisäädyn hierarkioiden standardoitumisessa ja naisten koulutien levenemisessä ja pitenemisessä eurooppalaisittain poikkeuksellisella tavalla (ks. Gripenberg 1909, 28-29 ja 45-50 ja 69-70; Wilkama 1938, 110-112; Elovainio 1971 ja Naumanen 1994, 65). Haataja (1990, 155-56) on huomioinut opettaja-ammatin muodostumisen naisten työksi ja Naumanen (1994) puolestaan tulkinnut aikuiskoulutuksen historiaa naisten opiskelun alueena. Kesäyliopistolaitos oli tässä kehityksessä olennainen koulutusorganisaatio, mutta se olisi jo oma tarinansa.

\section{Entä nyt?}

Kesäyliopistolaitos ei leikannut sisään vain koulutuksen organisoitumiseen, vaan vaikutti myös yliopistolaitoksen tutkimuskäytäntöjen organisoitumiseen. Tällaisissa kamppailuissa yliopisto-organisaation rajapinta aktivoituu. Sisäisen ja ulkoisen alueellistamisen erottelu on tässä olennaista, mutta institutionaalinen keskus eli tieteellinen tieto pyrkii pitämään organisaatiota kasassa. Koulutuksen relevanssin näkökulmasta jäsennetyille ulkoisille vaatimuksille herkistyminen on historiallisesti ottaen ollut osa akateemisen kentän sisäistä kamppailua, jota tiedon tuotannon vertikaalinen ja horisontaalinen struktuuri tutkintojen hallinnon kompetenssin puitteissa välillä rohkaisee, välillä jäykistää. Perustamisestaan aina kasvatustieteellisten tiedekuntien perustamiseen asti kesäyliopistolaitos oli instrumentti tällaisessa yhteiskunnallisessa merkityskokonaisuudessa. Tämän jälkeenkin sen merkitys korkeakoulutuksen organisoitumisen instrumenttina on ollut merkittävä, mutta 1990-luvulta lähtien monet koulutusorganisaation rakenneratkaisut ovat saattaneet sen yhteiskunnallisen merkityksensä suhteen uuteen etsikkovaiheeseen. Tässä se näyttäisi hakevan paikkaansa paikallisesti mutta alueellista luonnettaan uusissa oloissa syventäen.

Aikakausi ei kuitenkaan enää näyttäisi otolliselta sivistystahdon paikallisen esittämisen ja valtionrahoituksen toimintakaavalle. Mitä enemmän koulutusteollisuuden markkinat määrittävät kesäyliopiston perustaa, sitä todennäköisemmin tuo instituutio on muutoksessa. Kunnat palkkaavat kustannuslaskentaa painottavia elinkeino- tai innovaatioasiamiehiä. Usein haetaan alueen elinkeinorakenteen mukaisia alueliittymiä, jotka muodostavat niitä palvelevia koulutuskonserneja. Vanhan instituution uusintamisen mahdollisuudetkin ovat vielä olemassa, mutta erilaisina kombinaatioina. Nyt kyse on korkeakoulutuksen kompleksista, jossa alueyliopistot täydennyskoulutuskeskuksineen yhtyvät. Ammattikorkeakoulujen kirjo on osa panoraamaa. Samanaikaisesti näiden muutosten kanssa on EU:n kaltaisen laajenevan geopoliittisen kokonaisuuden tarjoamien rahoitusinstrumenttien merkitys kasvanut. Valtionavuin ja osin kuntataloudesta ammentavat paikalliset kesäyliopistot ovat tässä mielessä viimeisen 13 vuoden kuluessa joutuneet monessa suhteessa muuttuneeseen toimintaympäristöön.

Sikäli kuin kesäyliopistolaitoksen tulevaisuus liittyy yliopistolaitokseen - ei vain demagogisesti tai markkinaretorisesti - todellisten sosiaalisten käytäntöjen organisoitumisen merkityksessä, on kysyttävä, mikä on yliopisto? Sitä voidaan tarkastella joko instituutiona tai organisaationa. Bourdieuta ja Giddensiä yhdistelevä perspektiivi tarjoaa voimakkaan tavan analysoida akateemisen kentän käytäntöjen instituoitumista. Sitovien ja mahdollistavien, ajan kulussa tavanomaiseksi muodostuneiden toimintakaavojen valtakytkennät koetetaan tehdä näkyviksi ja luokituskamppailuiden yhteys vallankäyttöön selkeämmäksi. Kysymys toimijuuden konformismista tai vastarinnasta tulee nimettävään muotoon - kuten nyt - kun yliopistouudistus poistaa romanttisesti idealisoidun yhteisöllisyyden verhon ja esittää yliopisto-organisaation eriytyneisyyden paljaana. Yliopisto onkin käsitettävä vähintään kaksoiskohdentuneena organisaatiosysteeminä tai kenttänä. Yhtäällä on tieteellisen tiedon tuotanto ja toisaalla tiedon professionaalisten sovellusten kontrolli, missä kytkentä koulutukseen tulee ilmeiseksi. Näiden eriytyminen vaikuttaa yhä todennäköisemmältä. Tieteen ammattiin valmistavat koulutussyklit koulumaistuvat ja ammattimainen tutkimus suuntautuu yhä enemmän yritysmäiseen muotoon. Eriytyminen tuottanee näkyviä efektejä myös yliopistojen hallinnossa ja muissa tehtäväkokonaisuuksissa.

Yliopistojen tutkimukseen on instituoitunut kaksi olennaista ohjausperiaatetta; tieteellisen tiedon universaalisuus ja tiedon tuotannon avoimuus - salailun mahdollisuus on lähinnä teknisessä tietomuodossa, mutta siinäkin on riskinsä (Stichweh 2003). Tieteellinen tietomuoto kommu- 
nikoi totuuden kautta, mikä tarkoittaa yksityistotuuksien mahdottomuutta. Kyse on siitä, minkä tiede globaalina kommunikaatioyhteytenä voi käsittää itseensä sisältyväksi. Tieteellisen tiedontuotannon avoimuus tarjoaa mahdollisuuksia moninaisile tutkimuskäytännöille. Tässä voisi olla kesäyliopistolaitoksen paikka. Kyse on tieteen epäsuoran inkluusion strategioiden mahdollisuuksista, joita tuo välittäjäorganisaatio voi kehitellä. Stichweh (2003) esittää tällaisen välitysmuodon nimeksi popularisointia, mutta ei viitaa marginaaliseen tiedon levittämiseen, vaan myös tiedontuotannon ytimeen. Yliopistossa tutkijat joutuvat jatkuvasti popularisointihaasteen eteen. Kommunikaatioedellytysten huomioimisen vaatimus on tietenkin vielä suurempi, kun kyse on tieteenalojen välisistä yrityksistä tai kehitys- ja innovaatiotoiminnasta moninaisten yleisöjen odotusten edessä. Tieteen epäsuoran inkluusion funktionaalisena keskuksena on kasvatus ja (jatko)koulutus miksipä ei myös ns. vapaa sivistystyö. Miten kesäyliopisto kehittelisi inkluusion mahdollisuuksia?

Kesäyliopistolaitos ei voi enää edetä edeltävien vaiheiden mallissa, missä niiden kautta ilmenevä paikallisaloitteisuus saattoi kytkeytyä yliopiston tai filiaalin saamisen paikkakunnalle. Myös kesäyliopistojen kytkennät kuntasektorin ammatilliseen täydennyskoulutukseen ovat nykyisin tiukemman kustannuslaskennan raamittamia. Koulutuksen organisaation jäsentävä merkitys on niin ikään toisenlainen, kun suurempia ikäluokkia seuraa yleisen koulutustason nousu. Kesäyliopiston yhteiskunnallinen merkitys ei ilmene enää selvästi koulutusekspansion tukiorganisaationa. On syytä kiinnittää vakavaa huomiota kesäyliopistojen siihen toimintalinjaan, joka ilmentää kansansivistyksen ja nykyisen vapaan sivistystyön jatkumoa. Tällöin koulutuksen organisaatiokompleksin jäsentävä merkitys Luhmannin ja Schorrin (1988) tarkoittamassa uran koodissa muodostuu ongelmalliseksi. Sivistysharrastusten jäsentäminen uran ja selektion avulla menettää tässä katsannossa merkitystään. Oppilaitostyypin on mahdollista painottaa myös aidosti alhaalta lähteviä aluehahmotuksia ja korostaa opinnollisuuden välittämien sosiaalisten järjestysten tuottamisen moninaisuutta. Kesäyliopisto on asiantuntijaverkosto-organisaatio, mikä voi olla vahvuus. Kyse on ketterästä ja pienin kiintein kustannuksin toimivasta organisaatiosta, joka voisi olla avoin pedagogisen tilan moninaisuuksien mahdollisuudelle ja tiedontuotannon ja oppimisen sosiaalisten järjestelyjen uudel- le refleksiivisemmälle hahmotukselle. Nyt olisi koulutuksen ekspansiotendenssin uudelleen arvioimisen ja itse organisoituvan sivistystahdon uusien muotojen tukemisen puntaroinnin paikka. Tietoyhteiskunnassa pedagogisen tilan synnyttämiseen on runsaasti mahdollisuuksia.

\section{Lähteet}

Aaltonen, Markus (2000). Sivistyksen hinku. Etelä-Pohjanmaan Korkeakouluyhdistys.

Allardt, Erik (1966). Folksolläraren som samhällsmedlem. Finlands Folkskola 100 år 1866-1966. Finlands svenska folksskollärarförbund: Svenska folkskolans vänner, Helsingfors.

Bourdieu, Pierre (viitattu avoimesti)

Cavonius, Gösta (1982). Tanke och Gärning: Svenska folkskolans vänner 1882-1982. Borgå: SFV:s Förlag.

Elovainio, Päivi (1971). Opiskelijakunnan suuruus ja rakenne Suomen korkeakoululaitoksessa. Sosiologia, No.5 1971, 262-276.

Focault, Michel (1984). What is Enlightenment? Teoksessa; Rabinow, P. (ed) The Foucault reader. Pantheon Books, New York.

Giddens, Anthony (viitattu avoimesti)

Gripenberg, Alexandra (1909). Naisasian kehitys eri maissa IV, Suomi. WSOY, Porvoo.

Haataja, Anita (1990). Opettajan ammatti naisten työnä. Teoksessa; Haataja, A; Lahelma, E. ja Saarnivaara, M. (toim.) Se pieni ero. Kouluhallitus ja Valtion painatuskeskus, Helsinki.

Impivaara, Ilmo (1986). Turun kesäyliopisto 1936-1986. Turun kesäyliopisto, Turku 1986.

Jäntere, Kaarlo (1942). Turun yliopiston perustaminen, Helsinki: Oy Suomen Kirja.

Kangas, Lasse (1992). Jyväskylän yliopistokysymys 1847-1966. Tutkimus korkeakoulun perustamisesta ja kehityksestä yliopistoksi. Studia Historica Jyväskyläensia No. 44, Jyväskylän yliopisto, Jyväskylä 1992 .

Kant, Immanuel (1995). Vastaus kysymykseen: Mitä on valistus? Teoksessa; Koivisto, Juha, Mäki, Markku ja Uusitupa, Timo (toim) Mitä on Valistus. Tampere: Vastapaino.

Kantasalmi, Kari (2008). Yliopistokoulutuksen avoimuus ja refleksiivisyys: Suomalaisen yliopistoaikuiskoulutuksen rakenteistumi- 
sen analyysia. Kasvatustieteen laitoksen tutkimuksia 215, Helsingin yliopisto.

Kantasalmi, Kari (2010). Profession or Professionalism? Teoksessa; Jaakko Kauko, Risto Rinne \& Heli Kynkäänniemi (eds.) Restructuring the truth of schooling - Essays on discursive practices in the sociology and politics of education. FERA, 48, 150-175).

Ketonen, Kimmo (1997). Sun kasvois eesä, Suomenmaa: Turun yliopiston ylioppilaskunta 1922-1944. Turun yliopiston ylioppilaskunta.

Ketonen, Oiva (1959). Suomalainen Tiedeakatemia 1908-1958. Suomalainen Tiedeakatemia.

Klinge, Matti (1990). Helsingin yliopisto 19171990: Helsingin yliopisto 1640-1990. Vol. III. Helsinki: Otava.

Lackman, Matti (1998). Teoksessa; Salo, M.ja Lackman, M. (1998) Oulun yliopiston historia 1958-1993. Oulun yliopisto.

Laine, Lea (2005). 50 vuotta iloista oppimista. Etelä-Karjalan Kesäyliopisto 1955-2005. Itä-Suomen Yliopistoseura ry. Imatra.

Laurilehto, T.O.(1994). Länsi-Suomen kesäyliopiston ja Korkeakouluyhdistyksen toimintaa satakunnassa 1964-1994. Länsi-Suomen Korkeakouluyhdistys ry.

Luhmann, Niklas (viitattu avoimesti)

Luhmann, Niklas (2002). Das Erziehungssystem der Gesellschaft. Frankfurt am Main: Suhrkamp.

Luhmann, Niklas s \& Schorr, Karl Eberhard (1988). Reflexionsprobleme im Erziehungssystem. Suhrkamp, Frankfurt am Main.

Luutonen, Marketta (1983). Kesäyliopistot aikuiskouluttajana. Lisensiaattityö, Taloustieteen ja sosiaalipolitiikan laitos. Turun yliopisto.

Martikainen, Elina (2005). Oppia kesät kaikki: Tampereen kesäyliopisto 1985-2005. Tampereen Kesäyliopistoyhdistys ry.

Mehtonen, Lauri (2005). Moderniteetin jäljillä Tekstejä aistisuudesta, tiedosta ja sivistyksestä. Niin \& Näin -lehden julkaisusarja.

Metsikkö, J.O ja Oksanen, N. (1943). Suomen Kansakoulunopettajain Liitto: Piirteitä 50vuotisesta toiminnasta. Suomen Kansakoulunopettajain Liitto.

Naumanen, Päivi (1994). Tiedon, taidon ja vallan tiellä: Miesten ja naisten kouluttautuminen ja työ. Koulutussosiologian tutkimuskeskus raportteja 22, Turun yliopisto.
Nassehi, Armin (2004). Die Theorie funktionaler Differenzierung im Horizont ihrer Kritik. Zeitschrift für Soziologie 33(2), 98-118.

Nevala, Arto (1986). Pohjan rakentajasta joustavaksi täydennyskouluttajaksi: Pohjois-Karjalan kesäyliopisto 1966-1986.

Nordström, W.E (1945). Abo Akademi 19181943. Åbo Akademi.

Nordström, W.E. (1968). Academica Aboensis Rediviva 1918-1968. Ekenäs Tryckeri.

Nurmi, Veli (1995). Suomen Kansakoulunopettajaseminaarien historia. Helsinki: OAJ.

Oksala, Kaarle (1924). Jyväskylän kesäyliopiston kymmenvuotisesta toiminnasta. Kasvatus ja Koulu 1924.

Puntila, L.A. (1944). Suomen ruotsalaisuuden liikkeen synty. Helsinki: Otava.

Sainio, Matti (1962). Jyväskylän kesäyliopisto 1912-1936. Jyväskylän kasvatusopillisen korkeakoulun kesälukukausi 1962.

Siljander, Pauli (2002). Systemaattinen johdatus kasvatustieteeseen. Helsinki: Otava.

Sivonen, Seppo (2000). Education movements in Finnish universities from 1870 to the present. Teoksessa; Cooke, A. \& MacSween, A. (eds) The rise and fall of adult education institutions and social movements: The proceedings of the Seventh International Conference on the history of adult education. Peter Lang, Frankfurt am Main.

Stichweh, Rudolf(1996). Science in the system of world society. Social Science Information, $35(2), 327-340$.

Stichweh, Rudolf (2003). The multiple publics of science: Inclusion and popularization. Soziale Systeme 9(2), 210-220.

Stichweh, Rudolf (2005). Inklusion und Exklusion: Studien zur Gesellschaftstheorie. Transcript Verlag, Bielefeldt.

Vuorio, Kaija (2006). Lentoon: Kuopion yliopiston neljä vuosikymmentä. Kuopion yliopisto.

Wilkama,S. (1938). Naissivistyksen periaatteiden kehitys Suomessa 1840-1880-luvuilla. Pedagogis-aatehistoriallinen tutkimus. Helsinki: Suomen Historiallinen Seura XXIII.

Artikkeli saapui toimitukseen 15.11.2008.

Se viritettiin uudelleen työn alle talvella 2010 ja hyväksyttiin julkaistavaksi 30.7.2010. 